Sultan Qaboos University

\title{
Making Amends: The Transformation of Theseus and the Feminization of Marriage in A Midsummer Night's Dream
}

\begin{tabular}{c}
\hline Charles Campbell \\
\hline Assistant Professor \\
Department of English Language and Literature \\
College of Arts \& Social Sciences \\
Sultan Qaboos University
\end{tabular}




\title{
Making Amends: The Transformation of Theseus and the Feminization of Marriage in A Midsummer Night's Dream
}

\author{
Charles Campbell
}

\section{Abstract}

This study of Shakespeare's A Midsummer Night's Dream asks why Theseus changes his mind about forbidding the marriage of Hermia and Lysander and what this change means for the view of marriage developed in the play and for the experience of art which the play engenders. By emphasizing the love of women for each other, the vows of sisterhood and the cult of Diana, the play prepares the way for Theseus' change of mind and for the feminization of marriage and the celebration of imagination with which the play ends. We can observe these emphases in patterns of language and imagery (especially the flower motif), in metaphors and allusions and in descriptions of the union of opposites. The interplay of chaste love and desire delineates the art of metaphor and drama which the audience must grasp to fully appreciate the play. In Acts 4 and 5 Theseus' resistance to romantic love melts away, along with his opposition to the imagination. Thus, during the wedding feast of Act 5 , Theseus defends the amateur theatrics of the workmen as being excellent «if imagination amend them» (5.1.209); and he is associated in his language and ideas with Puck, the most fantastic and transformative character in the play. Theseus is himself transformed from the seducer and betrayer of women described in 2.1.77-80 into a worthy husband for Hippolyta, one who meets her halfway in her respect for the visions of lovers and poets.

Keywords: Amend, Feminine, Motif, Metaphor, Transformation

\section{صنع التعديلات: تحول ثيسيوس وتأنيث الزواج في مسرحية شكسبير

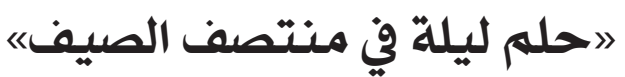

تشالز كامبل

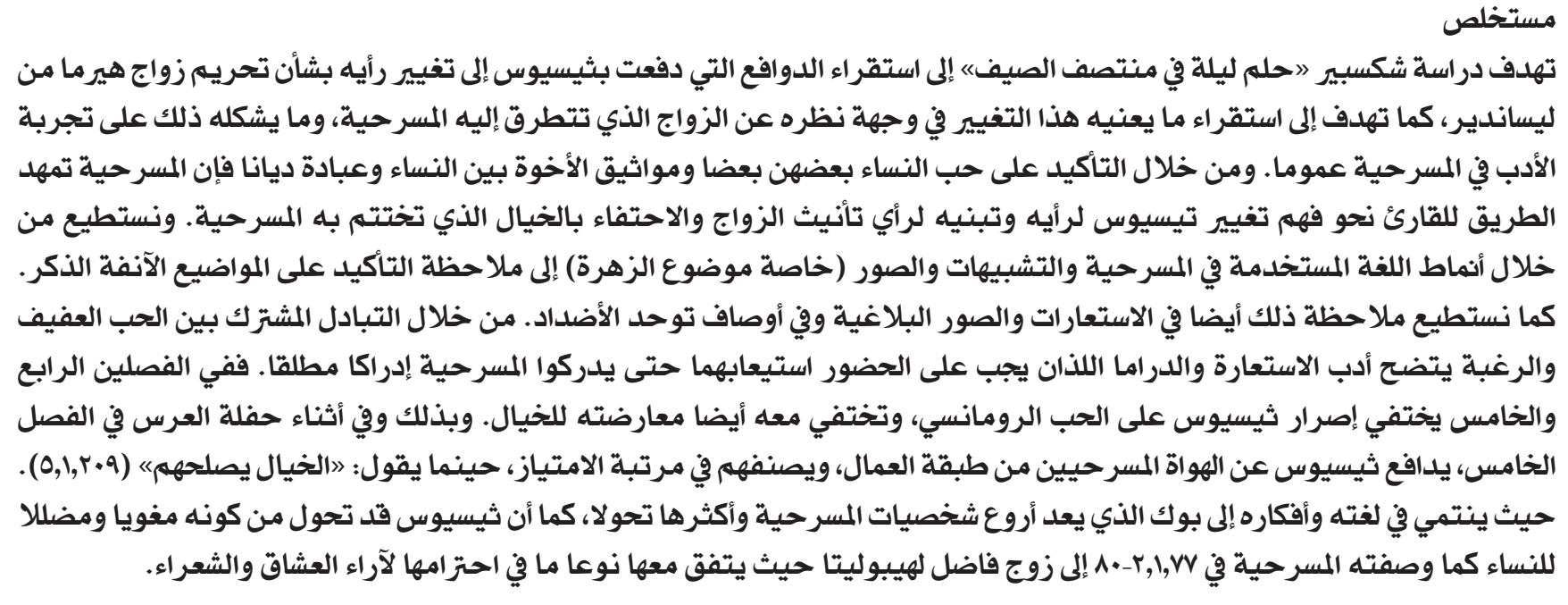


A Midsummer Night's Dream poses two problems in the logic of its plot: the first is why Titania gives up the Indian boy to Oberon and the second is why Theseus changes his mind about enforcing the law of Athens, overrules Egeus and approves the marriage of Lysander and Hermia. The first problem may be solved by considering Titania's deluded state at the time she makes her concession, so infatuated with the donkey-headed Bottom, what Oberon calls «her dotage», that her devotion to the boy fades and, when Oberon again asks for him, "straight she gave me». The context of her change of heart from her former obduracy, crowning Bottom's head «with coronet of fresh and fragrant flowers» and «in mild terms» begging Oberon's "patience», makes this reason plausible (4.1.46-62). Theseus' change of heart, the male and mortal match to Titania's, has a less manifest but equally remarkable cause. The female surrender to masculine domination in the fairy world of the forest matches a male surrender to the female principle in Athens.

Northrop Frye (1989) sets the reader on the right track when he points out that Theseus' remark after his ruling on the matter of Egeus and his willful daughter, "Come my Hippolyta; what cheer, my love?» (1.1.122), "seems a clear indication that Hippolyta . . . doesn't like this set-up at all» (Frye, 1989: 39). The 1998 film of the play directed by Michael Hoffman (1998) enlarges on Frye's insight by having Hippolyta break away from Theseus when he pronounces on the case in the first scene; and, when he says "come», she pointedly stalks off in the opposite direction. The same production has Theseus, in the first scene of Act 4, go apart and consult with Hippolyta before making his final decision on the case of Hermia:

Egeus, I will overbear your will;

For in the temple, by and by, with us,

These couples shall eternally be knit. (4.1.178180)

These words echo while directly contradicting his earlier pronouncement on the case:

For you, fair Hermia, look you arm yourself

To fit your fancies to your father's will;

Or else the law of Athens yields you up

(Which by no means we may extenuate)

To death, or to a vow of single life. (1.1.117-121) While the law and the father's will must be overcome in a classical comedy in order to have the life-affirming marriage at the end, the question of how this difficulty is overcome (the process of such a comedy's middle term) remains: What factors bring about Theseus' change of mind and heart? The answer is found by examining the nature of Hermia's prospective punishment, her "vows" to Diana "to live a barren sister all [her] life, / Chanting faint hymns to the cold fruitless moon» (1.1.72-73) and the persistence of this reference in the text. In this drama of many transformations, this study will seek to explain the transformation of Theseus by tracing the motifs of sisterhood, vows, Diana and the moon and thereby demonstrate the power of chaste female love in this play of male-female «fancies» (1.1.118) and "desires» (1.1.4 and 1.1.67).

Critics of $A$ Midsummer Night's Dream have seen a dichotomy in the play between the rational, maledominated daytime world of Athens (see, for example, Holland, 1995: 53) and the dream world of the forest, where feminine values make a stand (Hunter, 2009) and the importance of the irrational element of human nature to love and literary creation is affirmed (Garber, 1974: 60). An extreme but not atypical example of this binomial reading is Paul A. Olson's (1957) which sees the males Theseus and Oberon representing reason and the females Hippolyta and Titania representing passion. To Harold Brooks (2006), Theseus «stands for rational order» (p. ciii) and is "the prisoner of his rational . . cast of mind» (p. civ). For Peter Holland (1995), his "rationalist daylight skepticism» is "grotesquely inadequate to the experiences the play» reveals (p. 55; see also Grady, 2008: 229-230). A further opposition of reason and imagination has been maintained between Theseus and Hippolyta in their speeches in Act 5, with Theseus being "really a Philistine» while Hippolyta has the insight to see the truth of the lover's transfiguration in the forest (Muir, 1979: 47). Despite Theseus speaking the truth of the irrational that the imagination «apprehends more than cool reason ever comprehends," he is considered a skeptic who thinks players are mere "shadows» (Garber, 1974: 59) and whose «intent of scientific reasoning» ignores the scientific evidence for the truth of the lovers' story which Hippolyta points out (Ornstein, 1986: 88). "Metamorphosis for the eminently rational Theseus is a perturbation of the mind leading to a derangement of the perceptual apparatus»; while for Hippolyta "the transformation wrought by imagination ... when shared with others [is a] regenerating influence on human life» (Lucking, 2011: 150-151). Theseus makes his speech which defines the power of the creative imagination «in spite of himself»; while Hippolyta actively affirms how imagination can transfigure the world (Frye, 1989: 
48). For Rene Girard (1987), «Theseus ... understands nothing. Hippolyta understands everything» (p. 119). My reading, in considering Theseus' change of mind, sees a synthesis at the end rather than an opposition between the male and female points of view.

Another line of argument has patriarchal values dominating either throughout or at the end of the play-along with the destruction of female bonds. Louis Montrose (1983) sees the patriarchal norms which lead to rape (of Hippolyta by Theseus), forced marriage and treating a daughter as chattel in the play as "compensations for the vulnerability of men to the powers of women» (p. 77). Laura Levine (1996) agrees that the play opens with an originary rape which Theseus proposes to transform by revels (p. 217); however the violence against women built into the law of Athens is mirrored in the forest under Oberon's rule, so that one act of "sexual coercion begets another» (p. 215) and always events in the play work towards «the destruction of the bonds between women» (p. 226). Similarly, Garner (2001) sees the forest as a place where the challenge to "patriarchal and heterosexual values» is punitively answered by the humiliation of Titania and the final and irrevocable separation of Hermia and Helena, so that the joy at the conclusion is for the reinstatement of patriarchal order «satisfying men's psychological needs» at the cost of "the disruption of women's bonds with each other» (p. 127). Again in contrast, my reading will demonstrate the positive effect that female bonds, stressed throughout the play, have on the final presentation of marriage.

There are critical voices pointing away from the view of A Midsummer Night's Dream as a radically anti-feminist vision. Northrop Frye (1989) considers Theseus' change of mind in overruling Egeus as paradoxically overruling himself, compelled mysteriously «by fairies of whom he knows nothing and in whom he doesn't believe» (p. 40). Yet Frye maintains the dichotomy of reason and imagination, Athens and forest, men and women by giving Hippolyta all the credit for seeing the importance of the audience's imagination when she says «it must be your imagination then» (5.1.210), forgetting that the main point, how «imagination [will] amend them» (5.1.209), is stated by Theseus (Frye, 1989: 49). James Calderwood (1991) suggests, in a perception useful to my reading, that the forest scenes of Acts 2, 3 and 4 may be considered Theseus' dream arising from his anxiety about marrying an Amazon, and, since Oberon tightens masculine control over Titania, Theseus is able to loosen his patriarchal rule in Athens. Thus, by way of compensation, Titania's surrender of the Indian boy makes possible Theseus' change of mind about Hermia and Lysander. Also, Theseus' endless desire for different women is brought to rest by way of his dream of Titania as identified with Hippolyta. Dianne Hunter (2009) echoes Frye in seeing Athenian patriarchy «reformed by secret magical forces that subvert its harshness.» The drama takes the masculine ideas of marriage and paternity through the experience of «the green world [which] accommodates and supports female and prepatriarchal desires.» Marilyn French (1981) maintains the idea of dichotomy in A Midsummer Night's Dream, for her between imagination and constancy (p. 91). However, she points us in the right direction with her emphases on Shakespeare's "effort to harmonize moral qualities he did associate with the two genders» (p. 7), on «A Midsummer Night's Dream [as] a comedy about constancy that is filled with inconstant figures» (p. 253) and on Helena as a character who is «constant in the face of rejection, betrayal, undeserved hatred, [and] threat» (p. 163).

Burton Raffel (2006) notes that Theseus is "for an Elizabethan male ... remarkably deferential to his soon-to-be duchess» and also that "he is wise about the workings of the artistic mind» (p. xxii). Harold Brooks sees «rational Theseus» (Baumbach, 2013: 86) as sensitively concerned over Hippolyta's unhappiness about his ruling against the marriage of Hermia and Lysander and as "himself unhappy at the verdict» (2006, p. civ). Camille Slights (1993) observes that Theseus' "authoritative voice» becomes, from Act 4, Scene 1 on, "an articulation of the lovers' desires» (p. 122). In a fascinating insight that lends credence to my reading, Lisa Hopkins (2003) sees the play forming a wish-fulfillment dream of its women characters by its "self-conscious revisiting" of the anti-feminist myths of Phaedra, Medea and Helen of Troy.

The purpose of the present study is to recognize the change in Theseus, to see the reasons for and implications of this change and to show how this change is accounted for by the language and imagery of the text. Shakespeare does not write a patriarchal or a feminist tract; he writes a comedy. The question at the heart of a comedy is: How are the obstacles to love overcome? Love between women is a force that contributes rather than obstructs the successful unions of the several couples at the end of the play. To show how this is so, this reading will focus on the allusions to Diana, the descriptions of female friendships, the influence of chaste love on erotic love and the 
imagery of the moon, the snake, the flower, the love potions and the union of opposites. I emphasize the part the celebration of the bonds of women plays in the language of the play and their association with the transforming power of language and metaphor. I will show how the change worked by the dream world is experienced by Theseus and how the play ends with a compromise that feminizes the traditional patriarchal marriage. I will also show how the remarks of Theseus and Hippolyta in Act 5 coordinate to express the role of the reader's imagination the play requires and how Theseus changes his literal manner of reading, as with the law of Athens, to a strong appreciation of the «imagination [which] bodies forth / The form of things unknown" and "the poet's pen [that] / Turns them to shapes, and gives to airy nothing / A local habitation and a name» (5.1.14-17).

\section{Vows and Votresses}

Theseus' marriage is with the queen of the Amazons-she is the foremost representative of an all-female society who worshipped Diana. The cult of Diana is prominent throughout the play. From the first Theseus is bothered by the influence of the moon on his marriage: «How slow / This old moon wanes! She lingers my desires» (1.1.3-4). In describing Hermia's possible punishment, «to live a barren sister all your life, / Chanting faint hymns to the cold fruitless moon" (1.1.72-73), Theseus considers the worship of Diana a worthy role for a woman but not as satisfying as marriage:

Thrice blessed they that master so their blood

To undergo such maiden pilgrimage;

But earthlier happy is the rose distilled. (1.1.7476)

If she takes the way of the sister and the moon, Hermia will have to take "a vow of single life» (1.1.121). Throughout the play, women and sisterhood are associated with making and keeping vows while men's love is associated with broken vows.

Theseus marriage to Hippolyta represents a reformation of the scandalous record of his love affairs. Part of this record is detailed by Oberon in accusing Titania of loving Theseus:

Didst not thou lead him through the glimmering night

From Perigouna, whom he ravished;

And make him with fair Aegles break his faith,

With Ariadne and Antiopa? (2.1.77-80)

These are four of the women Theseus betrayed, including Antiopa, the Queen of the Amazons, whose kidnapping by Theseus caused the war when, in Shakespeare's version, he wooed and won Hippolyta "with my sword» (1.1.16). However, some sources have Hippolyta as another name for Antiopa, mother of Hippolytus by Theseus, and have her attacking Athens to avenge his betrayal on the day of his marriage to Phaedra (Grimal, 1991: 203 and 433-434). This tangled web forms the classical background to Shakespeare's account of the royal couple; in none of the mythical accounts does Theseus marry Hippolyta or Antiopa. Theseus represents therefore an archetypal version of men's infidelity, like Aeneas in Hermia's vow to meet Lysander in the woods:

And by that fire which burn'd the Carthage queen When the false Troian under sail was seen;

By all the vows that ever men have broke,

(In number more than women ever spoke). (1.1.173-176)

Men are the breakers of vows; women are the keepers of vows. Lysander "avouch[es]» how Demetrius broke his vows to Helena; then he himself, after the love potion is misapplied by Puck, breaks his vows of love to Hermia to reassign them to Helena as «vows so born» with weeping and thus «bearing the badge of faith» (3.2.124-127). Helena responds that in this "truth kills truth," since "these vows are Hermia's» (3.2.129-130).

Lysander's inconstancy enacts a dream Hermia has that expresses her fear of men's faithlessness, the only literal dream in a play where magic, imagination, poetry and drama are seen in relation to dreaming. Hermia's dream is a reversal of the myth of the Garden of Eden, with the snake representing man's betrayal eating the fruit of a woman's heart: «Methought a serpent ate my heart away, / And you sat smiling at his cruel prey» (2.2.148-149), as she says to Lysander who has already deserted her. The snake of Hermia's dream enters the language of the players to become the type of betrayal, with Hermia accusing Demetrius of Lysander's murder and lying about it: «An adder did it; for with doubler tongue / Than thine, thou serpent, never adder stung!» (3.2.72-73). Then Lysander rejects Hermia in similar terms: "I will shake thee from me like a serpent!» (3.2.261). Finally the serpent appears in the idea of the audience's rejection of the actors by hissing "if we shadows have offended" (5.1.409): «Now to 'scape the serpent's tongue, / We will make amends ere long» (5.1.419-420). Thus the image laces together the different levels of the play's reality: dream, love affair, magic spell and audience response. Metaphor is used to demonstrate men's infidelity. 
Demetrius is a serpent, and Lysander treats Hermia like a serpent. In recounting the change in Demetrius' affections, Helena uses a pun to introduce a metaphor for the insubstantiality of his promises:

For, ere Demetrius look'd on Hermia's eyne, He hail'ed down oaths that he was only mine; And when this hail some heat from Hermia felt, So he dissolv'd, and show'rs of oaths did melt. (1.1.242-245)

The play concerns the operation of metaphor as one of the powers, along with love, dreams and magic, of transformation. The motif of vows finds its focus in a passage that reveals metaphor as a theme as well as a method.

Like each of the pairs of lovers, there is an obstacle blocking the love of Oberon and Titania. For Theseus and Hippolyta it is time and the symbolic moon ("how slow / This old moon wanes»); for Lysander and Hermia, it is her father's disapproval and Theseus' enforcement of the law of Athens; for Demetrius and Helena, it is Demetrius' love for another. For Oberon and Titania the obstacle is the quarrel over control of the Indian boy. As various commentators have noted, this dispute involves the conflict between masculine rule and women's friendship. Frye (1989) notes that Titania is a name given to Diana once in Ovid (p. 45; noted also by Brooks, 2006: lix); and her possession of the boy is a matter of women's vows: «Her mother was a votress of my order» (2.1.123), "and for her sake I will not part with him» (2.1.137). In one of the finest passages in the play, Titania describes her friendship with the mother in a scene which enacts the process of metaphor:

And, in the spiced Indian air, by night,

Full often hath she gossip'd by my side;

And sat with me on Neptune's yellow sands,

Marking th' embarked traders on the flood:

When we have laugh'd to see the sails conceive

And grow big-bellied with the wanton wind;

Which she, with pretty and with swimming gait

Following (her womb then rich with my young squire),

Would imitate, and sail upon the land

To fetch me trifles, and return again

As from a voyage rich with merchandise.

But she, being mortal, of that boy did die;

And for her sake do I rear up her boy. (2.1.124136)

A scene of maternity with no hint of a father, the scene suggests the nascent British imperial connection to India (according to Margo Hendricks, 1996) but uses it to celebrate women's love for each other. The play of language that turns a ship into a pregnant woman and vice versa is here dramatized, making the magic of metaphor part of the varied metamorphoses of A Midsummer Night's Dream, part of the pattern in the text that includes the translation of Bottom. The comic realization in action of the metaphorical idea that Bottom is an ass here has its serious counterpart. A phenomenon of nature rather than sex, "the wanton wind» impregnates the ship. Mirroring and reversing the ship by sailing "upon the land," the Indian woman bears rich merchandise in the form of the boy who embodies the vow of love between the two women. The theme of language as transformation here has its richest representation in the play.

\section{"Both One Flower»}

Oberon is intent on taking the boy from Titania, and the resolution of their quarrel, which has disrupted the normal processes of nature, depends on that. While she is "enamour'd of an ass» (4.1.76), the Fairy Queen gives up her claim to the boy. However, it is important to examine the means by which this end is achieved, for at every step the magic transformations in the forest (which eventually reunite Demetrius and Helena and implicitly make Theseus allow the marriage of Lysander and Hermia) are conditioned not only by the forces of desire (Cupid) but also those of chastity (Diana). This is clear in the legend Oberon recounts of the formation of the flower he will use to "charm the eyes» of the lovers and Titania. Echoing Theseus' words about "the cold, fruitless moon," Oberon describes Cupid "flying between the cold moon and the earth» (2.1.156) and intending to hit "a fair vestal» with his arrow to make her fall in love; however, the shot goes awry:

But I might see young Cupid's fiery shaft

Quenchd in the chaste beams of the wat'ry moon;

And the imperial votress passed on,

In maiden meditation, fancy free.

Yet mark'd I where the bolt of Cupid fell:

It fell upon a little western flower, Before milkwhite, now purple with love's wound:

And maidens call it "love-in-idleness." . . .

The juice of it, on sleeping eyelids laid,

Will make or man or woman madly dote

Upon the next live creature that it sees.

(2.1.161-172)

Also part of the motif of the votress, this passage incorporates the influence of the chaste goddess Diana 
into the composition of the magic flower, since the arrow before striking the flower is «quenched in the chaste beams of the wat'ry moon.» In addition, to set things right with both Lysander and Titania, Oberon must use an antidote in the form of Artemesia, the flower of Artemis or Diana (Brooks, 2006, p. xc n. 72). This magic potion restores true vision and removes illusion:

Be as thou wast wont to be;

See as thou wast wont to see:

Dian's bud o'er Cupid's flower

Hath such force and blessed power. (4.1.70-73)

The magic power to create love is already imbued with the influence of Diana; and it is Diana's flower that sets mistaken love to rights. Most commentaries on the play omit to mention that there are two very different flowers involved in the magic in the forest, let alone that even the flower of desire is conditioned by the power of chaste love. This blend in the potions reflects the situation in the play as a whole.

The scene among the mortals that matches the scene of Titania and the Indian mother is the one described by Helena of "school-days' friendship, childhood innocence» and "sisters' vows» with Hermia (3.2.199202). This passage too functions to describe the art of A Midsummer Night's Dream as well as the love of women:

We, Hermia, like two artificial gods,

Have with our needles created both one flower,

Both on one sampler, sitting on one cushion,

Both warbling of one song, both in one key,

As if our hands, our sides, our voices and minds,

Had been incorporate. So we grew together,

Like to a double cherry, seeming parted,

But yet an union in partition,

Two lovely berries molded on one stem;

So, with two seeming bodies, but one heart;

Two of the first, like coats in heraldry,

Due but to one, and crowned with one crest.

(3.2.203-214)

Here the act of creation of the work of art is seen as a cooperative blending of two efforts, and the friendship that makes the work possible is like a double cherry, like a double shield with one crest, two bodies with one heart. The love of the two women embodies the form of the play which will unite man and woman but also desire and devotion, heterosexual and feminine love. Their "union in partition» describes also the incorporation of figure and frame in metaphor, reality and imagination in poetry and players and audience in dramatic performance. The creation by two figures of one flower on a sampler is a miniature of the whole text which brings together two kinds of love and symbolizes their conjunction in a flower with the magic power to arouse love and another flower to resolve mistaken love, two flowers making one lovers' union. The flower is the central image of transformation in the text, "and the focal hand-property in the Dream represents a metamorphosed flower» (Brooks, 2006: cii).

For Titania, flowers connect to Diana when she predicts rain and orders Bottom brought to her bower: "The moon, methinks, looks with a wat'ry eye,/ And when she weeps, weeps every little flower,/ Lamenting some enforced chastity" (3.1.191-194). The union of opposites operates in the uncertainty in this passage of whether the moon as Diana mourns a rape or "a more amorous Luna or Selene» mourns "a compelled preservation of chastity" (Baumbach, quoting Calderwood, 2013: 86).Oberon figures the absurdity of Titania's infatuation with Bottom in a similar imagery of weeping flowers describing a coronet that she has placed on the Ass's head in which the dew, «like round and orient pearls, / Stood now within the pretty flowerets' eyes / Like tears, that did their own disgrace bewail» (4.1.53-55). The flower motif miniaturized in Hermia and Helena's sampler of the text leads finally to the wedding night for all the Athenian couples, the action of which is indicated by one of Bottom's malapropisms in the play within the play, making death into the act of love: «Lion vile hath here deflower'd my dear» (5.1.281). The flower image forms the center of the play as it does of the creative friendship of Helena and Hermia as the design created by their incorporation.

\section{Double Visions}

Before the lovers go to the forest, Hermia identifies it to Helena as the place of their girlhood intimacy, "where often you and I/ Upon faint primrose beds were wont to lie,/Emptying our bosoms of their counsel sweet» (1.1.214-216). Lysander images the time of his elopement there with Hermia by reference to Diana and to double vision as «Tomorrow night, when Phoebe doth/ Her silver visage in the wat'ry glass behold/ Decking with liquid pearl the bladed grass» (1.1.209-211). The double image of Phoebe and her reflection is proleptic, looking forward to the state of mind the forest experience will engender in the lovers and the readers.

In between the forest and Athens, dream and waking life, the lovers are uncertain which is which. 
Hermia expresses this in-between state in terms of perception: «Methinks I see these things with parted eye,/ When everything seems double» (4.1.188189). Helena agrees and expresses the condition in terms of relationships: "So methinks;/ And I have found Demetrius like a jewel,/ Mine own, and not mine own» (4.1.189-191). Acting and viewing a play require double vision; love in A Midsummer Night's Dream is also a union in partition by which the force and compulsion of patriarch-defined heterosexual love is conditioned by the constant and unforced love of sisters; so that the loved one is «mine own, and not mine own.» This is the new vision that allows for Theseus' change of heart about the law and love and makes for the theory of art expressed in Act 5 of the play. There his rationalist critique of the «shaping fantasies» of madmen, lovers and poets becomes «an apology for poetry" as his «tone shifts from derogatory to laudatory [about] the awesome creative powers of 'the poet's pen'»(Ryan, 2009: 91). Thus he moves towards the «utopian and aestheticizing» "form of perception," characteristic of Oberon and Titania but usually lacking in humans, which the play promotes (Grady, 2008: 384).

The change in Theseus may be seen as a giving in to Hippolyta, certainly involves a giving in to the willful and unlawful love of Hermia for Lysander (an anti-patriarchal decision) and makes him, in Act 5, the foremost spokesman for the value of the imagination. It is he who unpragmatically encourages the tradesmen in their theatrics and leads the audience in the imaginative cooperation that makes them a success: "Our sport shall be to take what they mistake:/ And what poor duty cannot do, noble respect / Takes it in might, not merit» (5.1.9092). And, as the champion of the play with respect for the actor's efforts, he is also now a champion of love: «Love, therefore, and tongue-tied simplicity / In least speak most, to my capacity» (5.1.104-105). He reverses sides with Hippolyta who saw in the lover's fantastic story "something of great constancy; / . . strange and admirable» (5.1.26-27) but sees the performance of Pyramus and Thisbe as «the silliest stuff that ever I heard» (5.1.207). In contrast, Theseus admires the tradesmen who «never labour'd in their minds till now» (5.1.73) and promotes an imaginative identification with them: "If we imagine no worse of them than they of themselves, they may pass for excellent men» (5.1.211-212). In his role as audience motivator Theseus' words and attitude are reiterated by Puck in the concluding speech, which also excuses lack of skill with the honest intention to please. Both speak of actors as «shadows» (5.1.208 and 5.1.409), and Puck, like Theseus, begs the audience's indulgence so that the whole play-like Hermia in her dream, the lovers in their deluded conflicts and the tradesmen in their play--may "'scape the serpent's tongue» (5.1.419). Puck echoes Theseus' "the worst are no worse, if imagination amend them» (5.1.208-209) in his "Think but this, and all is mended» (5.1.410) and "Robin shall restore amends» in the play's final line. Theseus' voice and sentiments thus blend with those of the play's most fantastic character and master of transformation, who can change successively into "horse, hound, hog, bear, fire» (3.1.106).

Theseus must change his mind for the comedy to work; but Shakespeare makes him, as a result of this new attitude of mind, the spokesman for the power of imagination and promoter of audience sympathy for a play that invites ridicule. $\mathrm{He}$ is the reader in the text who can appreciate meta-theatre and also evoke a subtext: "And in the modesty of fearful duty / I read as much as from the rattling tongue / Of saucy and audacious eloquence» (5.1.101-103). He is the director in the play who makes Act 5 work as a dissertation on the imagination that incorporates the interchange of himself and Hippolyta and of the play and the audience. In the beach scene Titania expresses the interaction of figure and frame in metaphor; and Helena, in her memories of girlhood embroidery, represents the union in partition of Shakespeare's dramatic art. In Act 5, Theseus engineers the marriage of art and audience, imagination and mundane materials. The critic in the text, he ends the play by showing how imagination, like love in Helena's speech early in the play, "can transpose» "things base and vile ... to form and dignity» (1.1.232-233).

Theseus changes his mind, then, because he too is part of "those antique fables» he mentions (5.1.3), and he cannot remain the seducer and betrayer of women he is in those fables in Shakespeare's comedy. He changes his mind because the concept of marriage changes in the course of the play under the influence of passages depicting women's devotion, constancy and creativity in lovely figurative designs of moon, ship, snake and flower. Constancy is important in Shakespeare, as Hippolyta and Marilyn French point out. This ideal of fidelity is provided in the play by its accounts of women loving women in contrast to those of men loving women. The motif of vows leading to the wedding vows that occur offstage at the end, insofar as the vows are honoured, are those 
of women to women, to Diana and to men. The love potion responsible for the lovers' visions in the forest combines the powers of Cupid and Diana; while the potion which corrects all the mistaken visions is made from "Dian's bud.» Childbirth, the fulfillment of marriage which Oberon speaks of in his blessing of the marriage beds ( And the issue there create / Ever shall be fortunate» [5.1.391-392]), appears proleptically in Titania's account of her love for the Indian lady, where Shakespeare also places a preeminent example and dramatic enactment of the procreative power of metaphor. In the matching mortal scene of the creative love and "sister's vows" of Helena and Hermia, Shakespeare places his finest images of «union in partition» which stand, as part for whole, for the whole of a play that unites law and fantasy, royalty and workers, fairyland and Athens, actors and audience and libidinous and chaste love. In terms of the plot we may say that Theseus changes to make possible his marriage to Hippolyta. In terms of the language, imagery and allusions of $A$ Midsummer Night's Dream, he must change to be true to the text. Marriage in this play is manifold-of couples, realms of being, dramatic performance, social classes, desire and devotion and the figure and frame of metaphorall «incorporate ... like to a double cherry.» Theseus marries an Amazon worshipper of Diana, and the overcoming of all the obstacles to the play's happy resolution involves the incorporation of chaste feminine love into the vision of marriage, art and life the play finally achieves.

\section{References}

1. Baumbach, S. 2013. Voice, face and fascination: The art of physiognomy in A Midsummer Night's Dream." Shakespeare Survey 65, 77-91.

2. Brooks, H. 2006. Introduction. A Midsummer Night's Dream (pp.xxi-cxlii). ByWilliam Shakespeare. London: Arden.

3. Calderwood, J. L. Winter 1991. A Midsummmer Night's Dream: Anamorphosis and Theseus' dream. Shakespeare Quarterly 42(4), 409-430.

4. French, M. 1981. Shakespeare's division of experience. New York: Ballantine.

5. Frye, N. 1989. Northrop Frye on Shakespeare (R. Sandler, Ed.). Markham, Ont.: Fitzhenry and Whiteside.

6. Garber, M. 1974. Dreams in Shakespeare: From metaphor to metamorphosis. New Haven: Yale University Press.

7. Garner, S. N. 2001. “A Midsummer Night's Dream:
'Jack shall have Jill; / Nought shall go ill.'” In D. Kehler (Ed.),"A Midsummer Night's Dream": Critical essays (pp. 127-144). New York: Routledge.

8. Girard, R. 1987. "Bottom's one man show." In C. Koelb \& V. Lokke (Eds.), The current in criticism: Essays on the present and future of literary theory (pp. 99-121). West Lafayette, IN: Purdue University Press.

9. Grady, H. 2008. "Shakespeare and impure aesthetics: The case of A Midsummer Night's Dream." Shakespeare Quarterly 59(3), 274-302.

10. Grimal, P. 1991. The penguin dictionary of classical mythology (S. Kershaw, Ed.),(A.P Maxwell-Hyslop, Trans). London: Penguin.

11. Hendricks, M. Spring 1996. "Obscured by dreams':Race, empire and Shakespeare's $A$ Midsummer Night's Dream." Shakespeare Quarterly 47(1), 37-60.

12. Hoffman, M. (Director) 1998. William Shakespeare's "A Midsummer Night's Dream." United States: Fox Searchlight Pictures and Regency Enterprises.

13. Holland, P. (1995). Introduction. A Midsummer Night's Dream (pp. 1-117). By William Shakespeare. Oxford: Oxford University Press.

14. Hopkins, L. (2003). "Dreamtime: A Midsummer Night's Dream and the classical past." Shakespearean International Yearbook 3, 193205.

15. Hunter, D. 2009. "Cultural politics of fantasy in Shakespeare's A Midsummer Night's Dream." PSYART: A Hyperlink Journal for the Psychological Study of the Arts. December 15, 2009. Available http://www.psyartjournal.com/article/show/ hunter-cultural_politics_of_fantasy_in_shakespe. October 21, 2011.

16. Levine, L. 1996. Rape, repetition, and the politics of closure in A Midsummer Night's Dream." In V. Traub, M. Lindsay Kaplan \& D. Callaghan (Eds.), Feminist readings of early modern culture: Emerging subjects (pp. 210-228). Cambridge: Cambridge University Press.

17. Lucking, D. 2011. Translation and metamorphosis in A Midsummer Night's Dream. Essays in Criticism 61(2), 137-154.

18. Montrose, L. A. Spring 1983. 'Shaping fantasies': Figurations of gender and power in Elizabethan culture. Representations 1(2), 61-94.

19. Muir, K. 1979. Shakespeare's comic sequence. Liverpool University Press.

20. Olson, P. O. June 1957. A Midsummer Night's Dream and the meaning of court marriage. 
English Literary History 24(2), 95-119.

21. Ornstein, R. 1986. Shakespeare's comedies: From Roman farce to romantic mystery. Newark: University of Delaware Press.

22. Raffel, B. 2006. Introduction. A Midsummer Night's Dream (pp. i-xxiii). By William Shakespeare. New Haven, Conn. :Yale University Press.

23. Ryan, K. 2009. Shakespeare's comedies. London: Palgrave Macmillan.

24. Shakespeare, W. 2006. A Midsummer Night's Dream. (H. Brooks, Ed.). London: Arden.

25. Slights, C. W. 1993. Shakespeare' comic commonwealths. Toronto: University of Toronto Press. 